UDC 811'111'373.2

DOI https://doi.org/10.32838/2663-6069/2020.4-2/24

Nikiforova Ye. Yu.

Taras Shevchenko National University of Kyiv

Havryliuk O. O.

Taras Shevchenko National University of Kyiv

Galitska E. A.

Kyiv Gymnasium № 86 “Consul”

\title{
INTENTIONALITY AND ACCEPTABILITY AS STANDARDS OF TEXTUALITY IN PERFUME AND COSMETIC NAMES
}

The article deals with the problem of English perfume and cosmetic names and their textual properties. Special attention is paid to intentionality and acceptability as standards of textuality. Intentionality is recognized as text producer's intention to create a cohesive and coherent text. In the process of text production, a producer selects elements of the text which fit together and make sense. Elements selected in the text production process are grasped as language configuration that are intended to be a text and simultaneously are accepted to be utilized in communication. In the process of text production, text functions are relevant to the plan. The reception is relevant to the goal. The text producer has the intention of reconstructing a still unclear event. In this case, he/she shifts the plan for the utterance to reconstruct it. Speaking about perfume and cosmetic names which function as a four-block $(\boldsymbol{A}, \boldsymbol{B}, \boldsymbol{C}, \boldsymbol{D})$ text construct the shift of $\boldsymbol{B}$ text block meaning happens as the obligatory continuity of sense. The sense shift is a variant of regulatory actions. Intentionality in the perfume and cosmetic text constructions is realized as ways in which text producers utilize text constructions to pursue and fulfil their intentions. Perfume and make-up text constructions (B-text block, in particular) represent text producer's intentions involving the mechanism of correlation with the format and sense of utterances which affect text receivers. Grice's maxims are reflected in the text producers' actions represented in the text construction. Co-operation reflects the mutual activity of text producers and text recipients. In the practical point it is reflected in selling-buying procedure; and the contribution of participants as such as is required. Quantity makes the text construction as informative as is required. Quality is connected with truthfulness; false information is not represented in the text construction. Relation reflects the relevance of the text construction to the definite knowledge, to the given topic, to the usefulness in attaining some goal. Manner grasps five ways of arranging and delivering texts. Text producers should avoid obscurity of expression; distribute knowledge; avoid ambiguity; be brief; be orderly. There should be a correlation of actions with texts. Action is recognized as an intentional act which changes a situation in a way that would not have happened otherwise. Text production needs a definite planning and certain ability to envision alternative future states, work towards a particular goal, react to environmental conditions. Environmental conditions correlate to the market situation (selling, buying, advertising). Acceptability is understood as the text receiver's attitude in communication. Text receivers must accept a language configuration as a cohesive and coherent text capable of utilization. Acceptability is realized as the text receiver's ability to extract operating instructions from the utterance. Moreover, it is evident from the text and its situation of occurrence. Acceptability reflects what is actually accepted in communication. Text producers must be able to anticipate the receivers' responses as supportive or contrary to a plan by building an internal model of the receivers and their beliefs and knowledge.

Key words: acceptability, information and naming spaces, intentionality, perfume and cosmetic names, text producer, text recipient.

Introduction. The article's purpose is the research of perfume and cosmetic names in the aspect of intentionality and acceptability as standards of textuality. Perfume and cosmetic names reflect properties of these goods, such as fragrance, odour, colour, shade. Topicality is connected with the steady and stable tendency of modern linguistics to investigate language phenomena from different aspects with the purpose of finding mixed, intermediate, hybrid features of different language 
levels in the same unit-phenomenon. Perfume and cosmetic names being nominative units need to be investigated in the text aspect, focusing on standards of textuality. The scientific novelty lies in the fact that text properties of perfume and cosmetic names have not been investigated according to the text nature yet. No standards of textuality (intentionality and acceptability, in particular) were revealed in these names. The object of research is the names of perfume and cosmetic goods, and discursive space of perfume and make-up advertisement texts. The subject of the research is textual properties (intentionality and acceptability as standards of textuality) of perfume and cosmetic names and compositional and functional specification of these names.

Literature overview. Textual nature of perfume and cosmetic names has not been investigated yet. Standards of textuality were not applied to the perfume and cosmetic names too. Being the names of specific goods produced for different purposes of consumers, they were analysed according to the circulation of goods in the market. In particular, the pyramidal structure of the fragrance market is emphasized in the research. Social values seem to have been transformed under the influence of megabrands and new patterns of beauty [7, p. 889-901]. Goods that grasp a wide choice of perfumes and waters are known to be characterized with the tendency of strong aroma resemblance which is known as "tyranny of identity" [4, p. 14-16]. Old traditions and recipes of fragrances are being revived, all of them are associated with artistic perfumes. Smells of consumer goods which were known as "sad", "plain", "common are substituted by creating new and reconstructing old fragrances [9, p. 682-684]. There is no direct advertisement for artistic (selective, premium) perfumes. The Internet is involved in advertising [11, p. 26]. Having been founded in 1828, Guerlain is known to have started his activity with the production of cosmetic goods and only later his own perfumery was created [2, p. 72]. Creation of myth may lead to the brand ruining and its degradation to the level of ordinary consumer goods. There was a period between 1968-1978 when perfume Chanel № 5 was being sold everywhere in the USA, even in the drug stores [7, p. 898]. Considering consumers' memory any brand name should be easily pronounced and remembered, as well as have some definite sense [10, p. 194]. Having some sense, the name of goods helps consumers remember and recognize brand [7, p. 915]. The main feature of a brand name is its association with the category of goods, it should create a mental image in the consumers' brain
[3, p. 197]. The lipstick brand name analysis was provided from the textual point of view. Fourteen classification groups were singled out [8, p. 596-597]. That explains the integrated and complex nature of make-up nominative units. Harrison thinks perfume consumers are to be abandoned for creating their own image situations, using linguistic associations as a sense of direction [6, p. 8]. Social stratification investigations in the sphere of perfume and cosmetic nominative units were provided in the aspect of verbalization [5] but the standards of textuality were not involved in the analysis. Textual properties of perfume and cosmetic names need special attention as they can reveal communicative functions of nominative units. The detailed investigations of these communicative text structures can also trace the participants of communication reconstructing text producers and text receivers.

Results of the study and their discussion. Perfume and cosmetic names are applied to the goods of specific usage. Goods are the results of manufacture for a special purpose that are involved in market relations. The names of goods represent the quality features and substituting the goods function or the market representing them. The market relations include two main participants' groups. The first group grasps producers and sellers (in many cases they are one and the same). The second group consists of potential buyers and consumers. If the real goods are substituted with their names, the market relations may be understood from a bit different point of view. Market relation is a variant of communication. From the linguistic point of view, there are only two communicative units (the sentence is the smallest one, the text is the biggest one). The perfume and cosmetic names can be correlated with a text as a communicative unit. The corresponding perfume and cosmetic text has the intermediate position and functions as a mediator in the process of communication between a text producer and text recipient. The text producer corresponds to the producer of goods, the text recipient (receiver) correlates with the buyer (consumer). Being a central component in the process of communication, the text itself frames and outlines the phenomenon of text equilibrium where the processes of selling and buying from the branches of text balance, equilibrium. Creating a commodity, a text producer has a set of intentions. First of all, he/she intends to sell perfume or cosmetic goods full of advantage. For this purpose, he/she shows goods to good effect, giving positive information about goods, describing them from a different quality and quantity points. The producer represents information in a comfortable 
way for potential buyers, consumers, clients. It means that the text producer's activity is connected with intentionality. These standards of textuality outline the first branch of text equilibrium which moves from the text producer to the text and is associated with the selling. The second branch of text equilibrium moves from the text to the text receiver or recipient. It is connected with text recipients' activity. Being a text user, a text recipient-receiver has some potential ability to accept the text, extracting necessary pieces of information about quality, quantity, price and place of production. Text recipients' activity correlates with text standard of acceptability. In general, the phenomenon of text equilibrium may be kept within the bounds of intentionality and acceptability. Text as a point of intersection for these two standards of textuality is a fulcrum for communication providing stability for interaction between two main communicants. On the whole, the process of communication may be described with a consecutive chain: intentionality, text producer, text production, text, text reception, text recipient, acceptability. Applying the text equilibrium phenomenon to the perfume and cosmetic dealing it is possible to represent the chain of activity: intentionality, perfume and cosmetic producer, perfume and cosmetic text producer, selling the goods, perfume and cosmetic text, buying the goods, perfume and cosmetic consumer, acceptability. It is evident that perfume and cosmetic names have some connection with texts, and the correlation between name and text should be revealed and investigated. Perfume and cosmetic goods being represented on the consumer market are differentiated and identified with names or nomination complexes. In fact, a nomination complex outlines information space which contains main pieces of information about perfume and cosmetic goods. Perfume and cosmetic names are objective, reliable sources of information for potential buyers, users of these goods. Simultaneously these names are identity names and used by consumers for selecting corresponding goods. It proves that perfume and cosmetic names have both the information and naming spaces. The information space is built with lexical units. Approximately there are seven or eight lexical units in the perfume and cosmetic names (DIOR Hypnotic Poison eau de parfum spray $50 \mathrm{ml}$ ). The perfume and cosmetic naming space includes four nomination components (A brand component - VERSACE, B basic component - The Dreamer, $\mathbf{C}$ genitive component - eau de toilette, D functional-descriptive component - natural spray $50 \mathrm{ml}$ e 1,2 US. fl. oz.). On the point of crossing information and naming spaces, the perfume and cosmetic texts raise. These texts have integrated nature, consist of four text blocks which are reflections of corresponding four nomination components. Separated text blocks have the same properties as nomination components (A brand text block - ESTEE LAUDER, B basic text block - Youth Dew, C genitive text block - Roll-on antiperspirant deodorant, D functional-descriptive text block $150 \mathrm{ml}$ ). Multiblock structure of perfume and cosmetic texts permits to call them text constructions.

Intentionality is the first standard of textuality that should be traced and revealed in the perfume and cosmetic text construction. Intentionality is recognized as text producers' intentions to produce a cohesive and coherent text. Text producers' attitude is focused on the reflection of a set of occurrences. The reflection constitutes a cohesive and coherent text fulfilling the producer's intentions. The first intention is to distribute knowledge, the second one is to attain a goal specified in a plan [1, p. 217-219]. In the process of text construction creation, a text producer selects elements of the text in such a way that they fit together and make sense. The coherence of perfume and cosmetic text constructions is realized involving logical, topical connection which is reflected in the strict order of text blocks for all perfume and cosmetic goods. The text block chain ABCD is the only pattern for all text constructions. (A IVES SAINT LAURENT, B baby doll, C mascara, D volume effect e 6, 4 ml 0,21 fl. ox; A YVES ROCHER, B Shining Pastel, C nail polish, D pink). Cohesion in the same text constructions is realized involving the mechanism of lexical repetition when one and the same lexical unit is repeated in different text blocks. Repetition occurs between $\mathbf{A} \rightarrow \mathbf{B}$ text blocks (A. BVLGARI, B. BVLGARI MAN EXTREME), between $\mathbf{B} \rightarrow \mathbf{C}$ text blocks (B. L'EAU D'ISSEY, C. Eau de toilette), between $\mathbf{B} \rightarrow \mathbf{D}$ text blocks (B. Naturals body; D. Strawberry moisturizing body). The intentionality of text producer is realized in the process of choosing a language configuration. The most distinctive choice is necessary for $\mathbf{B}$ text block containing individual appellation of perfume and make-up goods. Language configuration forming $\mathbf{B}$ text block is intended to be a text, or text block, and simultaneously is accepted to be utilized in communication, consisting of two parts such as selling and buying. B text block is formed involving three types of naming units: words, phrases, sentences. Language configuration in our case is narrowed to $\mathbf{B}$ text block and according to the types of naming units there are three of them. Naming units as the representatives of language configuration are 
connected with the production and reception of text functions, and they are relevant to the plan and goal. For the qualitative research, the general corpus of perfume and cosmetic text structures was selected (3 430 items of entire excerption). The calculation shows 191 words which form B text blocks (Allure, Coco, Diorissimo, Y). There are only 22 sentences in the perfume and cosmetic text corpus. They are represented with imperative sentences (Make no mistakes. Live another day. Be delicious. Catch $<\ldots>$ me), declarative sentences (Tigress captivates. Love's Rain Scent), and exclamatory sentences with elliptical structure (Funny! Miracle so Magic!). The leading position belongs to the phrases or word combinations, there are 2130 phrases in the corpus. All the phrases are divided into parataxis and hypotaxis. Parataxis variants may be asyndetic and consist of two components Noun + Noun $(\mathrm{N}+\mathrm{N})$ : Anais Anais, Lou Lou, Ricci Ricci Couture Couture, Iris Tuberose, Master Corrector. Syndetic variants contain Noun + conjunction + Noun (NconjN): Love and Glamour, Dolce \& Gabbana, Jasmin and Bergamot, Kiss and Blush. Hypotaxis phrases consist of Adjunct and Head. The first structural type is represented with the basic model Adjective + Noun $(\mathrm{A}+\mathrm{N})$ : Pink Sugar, Cool Water, Beautiful Life, Fresh Rose, Purple Lilac. This first structural type may be divided into nine complicated subtypes. The complication may happen in Adjunct when instead of Adjective other parts of speech are used. The complication of Head takes place when instead of single Noun the inner word combination is used. The first complicated subtype corresponds to the formula Participle I + Noun (Ving + N): Sparkling Amethyst, Gleaming Gold, Blushing Fabric. The second complicated subtype correlates with formula Participle II + Noun $($ Ved $+\mathrm{N})$ : Sophisticated Violets, Sunkissed Effect, Whipped Cream. The third subtype includes Possessive Pronoun + Noun (I. + N): My Red, My Gold. In this subtype, Adjunct may be represented in preposition and postposition relative to Head Possessive Pronoun + Noun + Preposition + Objective Pronoun (I. + N + prep. + I.): Our Story for her, Our Story for him. Next four subtypes are complicated only in Adjunct. The Adjunct complication is varied according to the common, similar tendency. The fourth complicated in Adjunct subtype correlates with formula Adjective + Adjective + Noun $(\mathrm{A}+\mathrm{A}+\mathrm{N})$ : Little Black Dress, Retropical Blue Lagoon, Pure Color Crystal. The fifth complicated in Adjunct subtype correlates with formula Adjective + Noun + Noun $(\mathrm{A}+\mathrm{N}+\mathrm{N})$ : White Diamonds Lustre, Sexiest Fantasies Fireworks, False Lash Wings. The sixth complicated in Adjunct subtype corresponds to formula Noun + Adjective + Noun $(\mathrm{N}+\mathrm{A}+\mathrm{N})$ : Summer White Sunset, Cigar Black Wood, Mandarin Fruity Jelly. The seventh complicated in Adjunct subtype is connected with formula Adverb + Adjective + Noun $(\mathrm{D}+\mathrm{A}+\mathrm{N})$ : Very Irresistible Givenchy. The eighth subtype is complicated in Head. It is represented with formula Participle I + Noun + conjunction + Noun (Ving + NconjN): Nourishing Milk and Honey, Hydrating Peach and Cotton. The ninth subtype is complicated in Head too. It is described with formula Participle $\mathrm{I}+$ Noun + Noun + conjunction + Noun $\left(\right.$ Ving $+\mathrm{N}_{2}+$ $\mathrm{N}_{1}+\operatorname{conjN}$ ): Purifying Tea Tree and Cucumber. The second structural type is represented with the basic model where both Adjunct and Head are built with Nouns; Noun correlating with Head is represented as $\mathrm{N}_{1}$; Noun correlating with Adjunct is represented as $\mathrm{N}_{2}\left(\mathrm{~N}_{2}+\mathrm{N}_{1}\right)$ : Fantasy Midnight, London Beat, Berlin Playboy. There are eight complicated subtypes within the basic model. Three first subtypes are represented with complicated Adjuncts. Subtype 1 is completely formed with Nouns $\left(\mathrm{N}_{2(\mathrm{~N}+\mathrm{N})}+\mathrm{N}_{1}\right)$ : Lady Gaga Fame. Subtype 2 contains Adjective component $\left(\mathrm{N}_{2(\mathrm{~A}+\mathrm{N})}+\right.$ $\mathrm{N}_{1}$ ): Full Speed Adrenaline, Black Cat Eyes. Subtype 3 has Adjunct with preposition $\left(\mathrm{N}_{2(\mathrm{NprepN})}+\mathrm{N}_{1}\right)$ : Top to Toe Wash. Subtype 4 contains preposition between two Nouns $\left(\mathrm{N}_{1}\right.$ prep $\left.\mathrm{N}_{2}\right)$ : Garden of Eden, Flower in the Air, Stars in the Sky. Subtype 5 contains complication in Adjunct $\left(\mathrm{N}_{1}\right.$ prep $\left.\mathrm{N}_{2(\mathrm{~N}+\mathrm{N})}\right)$ : Extract of Skin Caviar. Subtype 6 demonstrated the complication in Head $\left(\mathrm{N}_{2}+\mathrm{N}_{1(\mathrm{~N}+\mathrm{N})}\right)$ : Glycerine Hand and Nails. Subtype $7\left(\mathrm{~N}_{(\mathrm{N}+\mathrm{N})}\right.$ conj $\left.\mathrm{N}\right)$ : Gold Amber and Tuberose, Sugar Plump and Vanilla. Subtype $8\left(\mathrm{~N}_{(\mathrm{A}+\mathrm{N})}\right.$ conj N): Oriental Orchid and Raspberry. Subtypes 7 and 8 have the intermediate position between parataxis and hypotaxis variants.

In the process of perfume and cosmetic text construction creation, the text producer (seller of the goods) creates the plan for utterance with the purpose of reconstructing a still unclear event. The creating of the event is connected with the formation of $\mathbf{B}$ text block. In the formation of $\mathbf{B}$ text block, the mechanism of continuity of sense as a typical regulatory action is realized involving the shift of meaning. Intentionality is recognized as ways in which text producers utilize texts to pursue and fulfil their intentions [1, p. 219]. Intentions are correlated with the format and sense of utterance. Applying intentions to the $\mathbf{B}$ text block creations, the format of $\mathbf{B}$ text block is represented with three types of naming units (words, phrases, sentences) involved in the formation of $\mathbf{B}$ text blocks, and the sense of $\mathbf{B}$ text block is represented with the naming register. Both format (three 
types of naming units) and sense (naming register), which correlate with the intentions, affect text receivers. Naming register is understood as a set of naming units having a different origin and used for creating $\mathbf{B}$ text blocks which are involved in perfume and cosmetic text construction. The naming register consists of two major branches and two marginal branches. The first major branch grasps the names of onym origin. It is formed involving the mechanism of transonymisation when one proper name is a source of another proper name (onym ${ }^{1} \rightarrow$ onym $^{2}$ ). The first major branch includes two transonymisation subbranches: anthtoponymies and toponymies. Another mechanism involved in the second major branch formation is onymisation when an appellative is the source of a proper name (appellative-onym). The second major branch contains nine lexico-semantic groups of the appellation register. Anthroponomic subbranch grasps a few groups of personal names. The first group includes names of fashion designers who expanded their business into the field of perfumery (Hugo Boss, Calvin Klein, Nino Cerutti, Donna Karan, Thierry Hermes, Ralf Lauren, Mary Kay Ash, Paco Rabanne, Tommy Hilfiger, Dante Trussardi, Gianni Versace, Yves Saint Laurent). Other representatives came to the field of perfume production from jewellery business (Sotiro Bulgari, Charles Lewis Tiffany, Rene Lalique, Paloma Picasso), haberdashery dealing (Thomas Burberry), professional sport (Michael Jordan, Rene Lacoste), actors (Elizabeth Taylor, Christina Aguilera, Laugh Often by Reese Witherspoon, Outspoken by Fergie), celebrities (Paris Hilton). Ordinary names are involved too ( $\mathrm{Lou} \mathrm{Lou,}$ Anais Anais, L'original, Valentina, Daisy). Toponymic subbranch includes toponymies. Geographical names are used as indicators of locations of headquarters connected with perfume and cosmetic dealing and producing (Paris, Paris Premieres Roses 2014, Jimmy Choo Flash, London Club Roma, Tokia Days, Tokia Fashion, London Beat). Other toponymies are used for creating $\mathbf{B}$ text blocks as they are associated with places of rest, entertainment, hustle-bustle life, tropical climate. These toponymies create positive associations with corresponding perfume and cosmetic goods (Fiji, Rio Glow, Grandda, Cashmere Mist, Down Town, Santo Domingo, Cuba Copacabana, Eden, Cuba Las Vegas). Nine lexico-semantic groups within the major branch of appellation register may be set out in logical order. The nearest to the anthroponymies is the first lexico-semantic group of social relations. It grasps the lexical units of gender differentiation (Woman, Duty Man), social status and title (Princess, Gentleman, Killer Queen, Lady
Million), social relations (Best Friends Forever). The second group contains lexical units of emotional and physical states, the reflection of patience, feelings (Guardians of Love, Love and Glamour, Thinking of Love, Obsession, Passion, Hypnose, Beyonce Heart Rush, Fantasy). The third group is the logical continuation of the previous one; there are unreal world phenomena, connected with emotions (Angel, Miracle, Miracle so Magic! Alien). Displays of intellectual and cognitive activity, especially in art branches are collected in the fourth group ( $\mathrm{Jazz}$, Romance, the Beat, Slow Dance, Passion, Dance, Poeme). Here it is possible to find out fashion design creativity (Design, Little Black Dress), sports and travel activity (Journey, Surf, Sport), estimate activity (Beautiful, The Original, Just Precious, Lucky You, Lucky Darling, Incognito, Curious). The fifth group is connected with real world representing lexical units of different substances. Here is the subgroup of precious stones and metals (Euphoria Liquid Gold, My Gold, Rare Gold, Gem, White Diamonds, Rare Pearls, Rare Sapphires, Sensual Amber), fabrics (Organza, Satine, Oriental Lace), substances with strong physiological action (Poison, Hypnotic Poison, Opium, Elixir), substances with specific properties (Irish Leather, Rouge, Cool Water, Coral Reef). The sixth group is logically connected with the previous one demonstrating colour palette (Red, My Red, Black $X_{s}$, Light Blue). The vast list of botanical terminology forms the seventh group (Sunflowers, Black Orchid, English Fern, Real Tree, Private Collection Jasmine White Moss, Flower Bomb, Elisabethan Rose, Orange Blossom, Flower in the Air, Flower of Immortality, Enchanted Forest, Body Fantasies Signature, Japanese Cherry Blossom). The eighth group grasps zoological terminology (Tigress Captivates, Cuba Jungle Tiger, Angry Birds Rio). The ninth group is connected with temporal segmentation indicating season and daily segmentation and periods (Today Tomorrow Forever, Fantasy Midnight, Summer, Eternity Night, Eternity Moment). B text blocks may form two marginal branches. The first marginal branch grasps borrowings. Sources of different languages are used for creating a naming register of perfume and cosmetic goods. The French language is traditionally the leading source of naming lexical units (Femme, L'Homme, Amor Amor, Magic Noir, J'Adore, Hot Couture, La Petite, Robe Noir Couture, Dahlia Noir, Champs Elysees, Parisienne). Italian borrowings are used too (Acqua Allegoria, Flora Rosa, Dolce Vita, Acqua Delle, Terre Rosse, Gelsomino Nobile, Acqua Di Parma, Rosse Nobile). Sporadically Portuguese (Escada) and Sanscrit 
(Shalimar, Samsara) borrowings happen in the naming register of perfumes and make-up. The second marginal branch grasps artificially created words (Lancosme, Lancome, L'Oreal). The structure of perfume and cosmetic naming looks very heterogeneous. It corroborates the varieties in the shifts of naming, reflecting the fluctuation of text producers' intentionality. In the process of text production, Grice's maxims are involved to create text constructions which may be used for effective conversation. Cooperation maxim makes text producer's contribution be up to the requirement. Perfume and cosmetic text constructions fulfil all requirements for effective selling and buying chosen goods. Quantity maxim makes text producer's contribution as informative as is required but not more informative than is necessary. ABCD text blocks are bearers of all necessary information. Quality maxim is connected with truthfulness. Text producers do not say what is false. Social obligation and responsibility are reflected in the process of selling. Relation maxim reflects the relevance of given information, it is related to given topics of perfume and cosmetics. Manner maxim grasps the ways of arranging and delivering perfume and cosmetic text constructions. It is recommended to avoid obscurity of expressions. Naming register used for $\mathbf{B}$ text block creation makes the information clear. If a text producer has motives for obscurity, he/she uses mysterious B text blocks, trying to attract the attention of potential buyers. It is recommended to avoid ambiguity and be brief. The text construction should not be cumbersome but it should be orderly. Text producer's materials are given in the order in which they are required. Standard ordering strategies are reflected in the order of ABCD text blocks. All these maxims create acceptability that is the text receiver's ability to extract operative instructions from the utterance. Acceptability is the text receiver's attitude in communication. Text receivers must accept a language configuration as a cohesive and coherent text capable of utilization [1, p. 287-291]. Acceptability and a text receiver are the final links in the chain of communication.

Conclusions. Perfume and cosmetic text constructions are formed after crossing the information and naming spaces. Individual properties of these text constructions are reflected in the quadro text block pattern. These text constructions possess such standards of textuality as intentionality and acceptability. These standards outline the process of communication in which a text producer and text recipient are involved. Communication includes two substages (selling and buying). Perfume and cosmetic text constructions are participants of text equilibrium and demonstrate features of traditional texts - the biggest communicative units.

\section{References:}

1. Beaugrande R. A. de, Dressler W. Introduction to text linguistics. London ; New York : Routledge, 1981. 286 p.

2. Briot E. Fashion Sprayed and Displayed: The Market for Perfumery in Nineteenth Century Paris. Proceedings of the Economic History Society Annual Conference. Exeter : Publishing University of Exeter, 2007. P. 69-72.

3. Chernatony de. L., Donald E., Wallance E. Creating Powerful Brands. London : Taylor and Francis, 2011. 249 p.

4. Dixit S. Fragrance Business Trends. Chemical Business. New York, 2009. № 23 (6). P. 11-26.

5. Galitska E. A. Social Factor verbalization in the perfume and cosmetic naming. Science and Education. A New Dimension. Philology. Budapest, 2016. IV (25). Issue 105. P. 20-23.

6. Harrison M. E. The Scented Word: Context, Intrigue and the Problem of Olfactory Literacy. Fragrances Supplement to Household and Personal Care Today. London, 2010. № 1. P. 6-10.

7. Jones G. Globalization and Beauty : A Historical and Firm Perspective. EURAMERICA. New York, 2011. № 41 (4). P. 885-916.

8. Merskin D. Truly Toffee and Raisin Hell: A Textual Analysis of Lipstick Names. Sex Roles. New York, 2007. № 56. P. 591-600.

9. Nappeney C., Endrissat N., Lzicar R. Consistent, Authentic and Emotional: Design-based Innovation in Artistic Perfumery. Leading Innovation Through Design. Proceedings of the DMI 2012 International Research Conference. 2012. P. 681-691.

10. Petty R. D. Naming Names : Trademark Strategy and Beyond : Part one. Selecting a Brand Name. Journal of Brand Management. New York, 2008. № 15. P. 190-197.

11. Walker R. A Challenging Global Climate for Fragrances. Global Cosmetic International. London ; New York, 2012, November. P. 26-29.

\section{Нікіфорова Є. Ю., Гаврилюк О. О., Галицька Є. А. ЦІЛЕСПРЯМОВАНІСТЬ І АЦЕПТОРНІСТЬ ЯК СТАНДАРТИ ТЕКСТУАЛЬНОСТІ В ПАРФУМЕРНО-КОСМЕТИЧНИХ НАЗВАХ}

Стаття висвітлюе специфіку парфумерно-косметичної номінації в англійській мові з огляду на текстову природу парфумерно-косметичних назв. Особливу увагу приділено таким стандартам 
текстуальності, як иілеспрямованість і акцепторність. Цілеспрямованість реалізується в парфумерно-косметичних назвах як текстова категорія, щзо віддзеркалює наміри текстопродуцента створити иілісний $i$ зв'язаний текст. У процесі створення тексту текстопродуцент відокремлює текстові елементи, що припасовані один до одного та формують сенс. Виокремлені у процесі створення тексту елементи як мовна конфігурачія та як такі, що спрямовані бути текстом, вони водночас сприймаються як одиничі для подальшої комунікаиії. У процесі продукування тексту його функиії співвідносяться з метою. Текстопродуцент має за мету реконструювати все ще нечітко репрезентовану подію, тому він змішує план висловлювання, щзоб реконструювати цю подію. Стосовно парфумерно-косметичних назв, щзо функиціонують як квадроблоковий $(\boldsymbol{A}, \boldsymbol{B}, \boldsymbol{C}, \boldsymbol{D})$ текстовий конструкт, зсув значення В текстового блока відбувається як обов 'язкове розширення сенсу. Цей зсув є варіантом регулятивних дій. Цілеспрямованість у парфумерно-косметичних текстових конструктах реалізується як шияхи, за допомогою яких текстопродученти використовують текстові конструкти для досягнення намічених иілей. Парфумерно-косметичний текстовий конструкт (В текстовий блок, зокрема) реалізує наміри текстопродуцента за допомогою механізму корелячії з форматом і сенсом висловлювання. Ці висловлювання впливають на текстореципієнтів. Максими Грайса відображені в діях текстопродуцентів, щчо віддзеркалені в текстовому конструкті як кооперація, кількість, якість, зв'язок, спосіб дії. Ці п'ять максим є провідними у процесі формування текстового конструкта. Максима кооперації відображає взаємодію текстпродуцентів і текстореципієнтів. У практичному ракурсі - це віддзеркалення у процесі купівлі та продажу парфумерно-косметичної продукції, а внесок иієї кооперації відповідає потребам комунікантів. Максима кількості робить текстовий конструкт інформативним відповідно до потреби. Максима якості пов'язана з достовірністю інформачії, неправдива інформачія неприпустима в текстовому конструкті. Максима зв'язку відображає релевантність текстового конструкта чітким значенням, визначеності теми, сенсу досягнення певної мети. Максима способу дії охоплюе п'ять шияяхв ранжирування і репрезентаціі текстів. Текстопродуценти повинні уникати невизначеності виразів, чітко сегментувати знання, уникати інформаційного перевантаження, бути стислими в обсязі інформації, а також бути послідовними в діях. Корелячія дій і текстів повинна мати місие. Дія розуміється як иілеспрямований акт, щзо змінює ситуацію таким способом, щоб запобігти іншим діям. Створення текстів потребує чіткого планування, яке є здатністю передбачати в майбутньому варіативність станів, рух до наміченої мети, реакцію зовнішнього оточення. Ці чинники співвідносяться з ринковою ситуацією (продаж, купівля, реклама). Акцепторність розуміється як позиція текстопродуцента в ситуації. Тестопродуценти повинні сприймати мовну конфігурацію як иілісний $і$ зв'язний текст, придатний до застосування. Акиепторність є здатністю текстопродуцента виокремлювати з висловлювання інструкиії до подальших дій. Акиепторність є очевидною із самого тексту та ситуаиій, щзо описані в ньому. Акцепторність відбиває те, щз саме було сприйняте у процесі комунікації. Текстопродуценти мають бути здатними до передбачення дій текстореципієнтів в аспекті підтримування або опору плану шляхом побудови внутрішньої моделі реципієнтів, їхніх переконань і знань.

Ключові слова: акиепторність, інформаційна і номінативна сфери, парфумерно-косметичні назви, текстопродуцент, тексторецииієнт, цілеспрямованість. 